\title{
Rancang Bangun Sistem Monitoring Listrik Tiga Fasa Berbasis Wireless Sensor Network Menggunakan LoRa Ra-02 SX1278
}

\author{
Aditya Pratama ${ }^{1}$, A. A. Ngurah Amrita ${ }^{2}$, Duman Care Khrisne ${ }^{3}$ \\ [Submission: 11-10-2021, Accepted: 16-12-2021]
}

\begin{abstract}
In the electrical system, monitoring helps us prevent and overcome disturbances and ineffective use of electrical energy. Electricity monitoring is currently carried out using simple measuring instruments and recording measured values manually. Designing a long-distance three-phase electricity monitoring system based on a wireless sensor network (WSN) using LoRa communication will overcome these shortcomings. The system consists of a transmitter node as a measuring instrument for voltage, electric current, frequency, power factor, and active power by utilizing the PZEM-004T module. The receiver node operates as a gateway which can receive data from the transmitter node wirelessly. The database will store the incoming data from the receiver via a server using the internet. When the internet is not available, the microSD card will carry out the saving process of the data. Web monitoring is designed to make it easier for users to access electricity monitoring data. Web monitoring will display data on voltage, electric current, frequency, and power factor in single-phase systems and active power in the three-phase form in tables and graphs.
\end{abstract}

Intisari - Pada sistem kelistrikan, monitoring perlu dilakukan untuk mengatasi terjadinya gangguan dan pemanfaatan energi listrik yang kurang efektif. Monitoring listrik saat ini masih dilakukan menggunakan alat ukur sederhana dan pencatatan nilai terukur secara manual. Kekurangan tersebut dapat diatasi dengan merancang sebuah sistem monitoring listrik tiga fasa jarak jauh berbasis wireless sensor network (WSN) menggunakan komunikasi LoRa. Sistem yang dibangun terdiri dari node transmitter sebagai alat ukur tegangan, arus listrik, frekuensi, faktor daya, dan daya aktif dengan memanfaatkan modul PZEM004T. Node receiver berfungsi sebagai gateway yang dapat menerima data dari node transmitter secara wireless. Data yang diterima receiver kemudian disimpan ke database melalui server menggunakan jaringan internet. Ketika node receiver tidak terkoneksi dengan jaringan $\mathrm{WiFi}$, data akan secara otomatis disimpan pada micro SD card. Web monitoring dirancang untuk memudahkan pengguna mengakses data monitoring listrik. Web monitoring akan menampilkan data tegangan, arus listrik, frekuensi, dan faktor daya dalam sistem satu fasa serta daya aktif dalam bentuk tiga fasa ke dalam bentuk tabel dan grafik.

Kata Kunci-Monitoring Listrik, WSN, LoRa, PZEM-004T.

\section{Pendahuluan}

${ }^{1}$ Mahasiswa, Program Studi Teknik Elektro Fakultas Teknik Universitas Udayana, Link. Br. Umalas Kauh, Kuta Utara, Badung, Bali 80361 INDONESIA (telp: 085333389189; e-mail: adityapratama141198@gmail.com).

2, ${ }^{3}$ Dosen, Program Studi Teknik Elektro Fakultas Teknik Universitas Udayana, Jln. Jalan Kampus Bukit Jimbaran 80361 INDONESIA (telp: 0361-703315; ${ }^{2}$ e-mail: ngr_amrita@unud.ac.id, ${ }^{3} e$-mail:duman@unud.ac.id).

Aditya Pratama: Rancang Bangun Sistem Monitoring...
Energi listrik dalam keberlangsungan hidup manusia memiliki peran yang begitu penting. Pada sektor komersial, industri, dan rumah tangga, seluruh sektor ini memerlukan energi listrik. Energi listrik digunakan untuk mensuplai beban listrik seperti perangkat elektronika dan mesin listrik. Manajemen listrik menjadi populer karena konsumen energi listrik ingin menjaga kualitas listrik yang diterima, ataupun pengelolaan terhadap pemakaian energi listrik. Monitoring listrik menjadi salah satu bagian dari manajemen listrik yang memiliki fungsi untuk mengamati atau memantau kondisi kelistrikan pada suatu tempat atau area. Monitoring listrik biasanya dilakukan menggunakan alat sederhana untuk mengukur parameter listrik yang diperlukan dengan pencatatan nilai terukur masih dilakukan secara manual. [1].

Teknologi terus mengalami perkembangan dari segala aspek termasuk pada bidang internet, saat ini internet bukan hanya dapat menghubungkan manusia dengan manusia, melainkan juga dapat menghubungkan antara manusia dengan perangkat, maupun satu perangkat dengan perangkat yang lain. Internet of Things (IoT) merupakan gambaran komunikasi digital yang memungkinkan berbagai perangkat sensor saling berkomunikasi antara satu perangkat dengan yang lain menggunakan media internet dikenal dengan Internet of Things (IoT) [2]. Sistem monitoring listrik dengan memanfaatkan IoT dapat mendukung untuk melakukan monitoring listrik secara otomatis dengan memberikan kemudahan di mana pada database data monitoring disimpan secara online, sehingga dapat dipantau dan diambil dari lokasi di mana saja selama internet tersedia [3]. Pada sistem monitoring listrik otomatis ini diperlukan perangkat yang melakukan sensing dan perangkat gateway untuk mengirimkan data ke database. Pada proses pengiriman data ke database perangkat monitoring memerlukan jaringan internet untuk mengirimkan data ke penyimpanan database, hal tersebut akan menjadi kendala ketika perangkat monitoring listrik yang diletakan pada panel listrik tidak berada dalam area akses jaringan internet, sehingga pengiriman data ke database tidak dapat dilakukan.

Keterbatasan ini, dapat diantisipasi dengan menggunakan teknologi LoRa (Long Range) yang bekerja dengan memanfaatkan radio frekuensi untuk berkomunikasi antar perangkat. Kelebihan yang dimiliki oleh teknologi LoRa adalah memiliki jangkauan komunikasi yang luas dengan konsumsi daya yang rendah [4]. Monitoring listrik memerlukan sensor untuk melakukan pengukuran parameter listrik, sensor-sensor ini akan mengirimkan data hasil monitoring ke sebuah data center melalui base station sebelum akhirnya disimpan pada database. Jaringan yang terbentuk oleh sensor, base station, dan data center tanpa menggunakan kabel untuk saling berkomunikasi disebut wireless sensor network (WSN). Peran p-ISSN:1693 - 2951; e-ISSN: 2503-2372 
teknologi LoRa pada jaringan WSN ini adalah sebagai penghubung komunikasi wireless antara perangkat sensor dengan data center.

Penelitian terkait pemanfaatan komunikasi dengan menggunakan LoRa telah banyak dilakukan. Beberapa diantaranya adalah penelitian yang dilakukan oleh Suga dan Nurwarsito pada tahun 2021, merancang sebuah sistem monitoring KWh meter yang memanfaatkan komunikasi LoRa, sistem monitoring mengirimkan data pemakaian $\mathrm{KWH}$ dari node sensor menuju gateway menggunakan komunikasi LoRa, kemudian data pembacaan sensor diteruskan menuju broker menggunakan protokol MQTT. Pengukuran daya dan energi listrik dilakukan menggunakan modul PZEM-004T, sedangkan modul LoRa yang digunakan adalah jenis LoRa SX1278 dengan hasil pengujian menunjukan transmisi data LoRa terbaik pada jarak 100 meter sampai 300 meter [5].

Penelitian selanjutnya oleh Darmawan dan Setyawan pada tahun 2018 membahas mengenai rancang bangun sebuah sistem monitoring solar cell yang khusus monitoring arus dan tegangan menggunakan transmisi LoRa. Sistem monitoring tersusun atas node transmitter dan node receiver, di mana node transmitter bertugas untuk melakukan pembacaan nilai arus dan tegangan pada solar cell, sedangkan node receiver bertugas untuk menyimpan data pembacaan sensor. Modul LoRa digunakan untuk menghubungkan antara antara node transmitter dengan node receiver, jenis modul LoRa yang digunakan adalah LoRa SX1278 [6].

Pada penelitian oleh Alfan, Murdiyat, dan Gunanto pada tahun 2021 membahas mengenai rancang bangun sensor node untuk sistem monitoring listrik pada Gedung Kampus Politeknik Negeri Samarinda. Penelitian ini menggunakan modul PZEM-004T sebagai sensor pembaca besaran listrik antara lain tegangan, arus listrik, frekuensi, faktor daya, daya aktif, dan energi listrik pada sistem listrik tiga fasa. Pada pengujian modul PZEM-004T diperoleh kesalahan relatif untuk nilai tegangan $0,291 \%$, untuk nilai arus 2,634\%, untuk nilai daya aktif $2,449 \%$, untuk nilai faktor daya 6,5055 dan untuk nilai frekuensi 0, 256\%. Modul LoRa SX1276 dengan frekuensi $915 \mathrm{MHz}$ digunakan untuk menghubungkan node sensor dengan gateway, hasil pengujian menunjukan bahwa pada pengujian transmisi data LoRa pada jarak 111.32 meter berhasil dikirimkan. Hasil akhir dari monitoring listrik ditampilkan ke dalam halaman situs web atau website [7].

Berdasarkan beberapa penelitian terkait sebelumnya, terdapat beberapa kekurangan dari sistem yang dirancang antara lain belum terdapatnya penyimpanan cadangan ketika gateway tidak terhubung dengan internet, pengujian transmisi LoRa masih sebatas menggunakan satu buah node sensor dan satu buah gateway, serta data yang ditampilkan bentuk sistem listrik tiga fasa. Sehingga pada penelitian ini dirancang sebuah perangkat monitoring listrik yang dapat melakukan monitoring listrik pada sistem tiga fasa dengan memanfaatkan teknologi LoRa untuk menghubungkan node sensor dengan gateway secara wireless. Parameter yang dapat diukur menggunakan modul PZEM-004T meliputi tegangan, arus listrik, frekuensi, faktor daya dan daya aktif. Pada perangkat gateway data yang diterima akan dilanjutkan menuju komputer server untuk disimpan pada database secara online. Pada sistem yang dirancang dilengkapi dengan penyimpanan cadangan menggunakan SD card, ketika kondisi gateway tidak sedang terhubung dengan jaringan internet. Hasil akhir akan menampilkan data tegangan, arus listrik, frekuensi, dan faktor daya dalam sistem satu fasa, serta menampilkan daya aktif dalam bentuk sistem tiga fasa pada halaman web monitoring.

Manfaat dari penelitian ini diharapkan pengiriman data hasil pembacaan sensor ke database online tidak terkendala pada ketersediaan jaringan internet pada perangkat yang dipasangkan pada panel listrik dan terdapat sistem informasi yang memudahkan pengguna listrik melakukan monitoring penggunaan energi listrik dengan mengakses web monitoring.

\section{TINJAUAN PUSTAKA}

\section{A. Parameter Listrik Arus Bolak Balik Tiga Fasa}

Sistem listrik tiga fasa merupakan metode yang paling umum digunakan untuk mendistribusikan listrik arus bolakbalik (AC) dengan kapasitas daya yang besar, sistem listrik tiga fasa merupakan bagian dari sistem polifase. Pada umumnya sistem listrik tiga fasa menggunakan empat kawat terdiri dari tiga buah penghantar fasa dan satu buah penghantar netral atau ground [8]. Pada listrik AC terdiri dari beberapa parameter yaitu: tegangan, arus, frekuensi, faktor daya, dan daya listrik.

1) Tegangan: Tegangan merupakan besarnya beda potensial antara satu titik ke titik lainnya yang memiliki satuan volt (V) [7]. Pada tegangan bolak-balik memiliki dua nilai polaritas yang selalu berubah-ubah, polaritas tersebut bernilai negatif dan positif. Nilai tegangan terukur pada alat ukur adalah nilai tegangan RMS [9]. Tegangan efektif pada rangkaian listrik dapat ditulis dengan persamaan (1).

$$
\begin{aligned}
& V_{R M S}=\sqrt{\frac{1}{T} \int_{0}^{T} V(t)^{2} d t}=\frac{1}{\sqrt{2}} \times V_{P} \\
& V(t)=V_{p} \sin (2 \pi \times f \times t)
\end{aligned}
$$

$$
\begin{aligned}
& \text { Keterangan: } \\
& V_{R M S}=\text { Tegangan efektif }(\mathrm{RMS})(\mathrm{V}) \\
& V_{P} \quad=\text { Tegangan puncak }(\mathrm{V}) \\
& f \quad=\text { frekuensi }(\mathrm{Hz}) \\
& t \quad=\text { waktu }(\mathrm{s})
\end{aligned}
$$

2) Arus Listrik: banyaknya muatan listrik yang mengalir pada sebuah penghantar listrik yang dihitung dalam satu detik disebut dengan arus listrik. Berlaku hal yang sama pada arus listrik AC, untuk nilai arus listrik AC yang terukur pada alat ukur juga adalah nilai arus RMS [9]. Arus RMS atau efektif pada rangkaian listrik dapat ditulis dengan persamaan (3).

$$
\begin{aligned}
& I(t)=I_{p} \sin (2 \pi \times f \times t) \\
& \text { Keterangan: } \\
& I_{R M S}=\text { Arus efektif }(\mathrm{A}) \\
& I_{P} \quad=\operatorname{Arus} \text { puncak }(\mathrm{A}) \\
& f \quad=\text { frekuensi }(\mathrm{Hz})
\end{aligned}
$$$$
I_{R M S}=\sqrt{\frac{1}{T} \int_{0}^{T} I(t)^{2} d t}=\frac{1}{\sqrt{2}} \times I_{P}
$$ 
Majalah Ilmiah Teknologi Elektro, Vol. 20, No.2, Juli-Desember 2021

DOI: https://doi.org/10.24843/MITE.2021.v20i02.P20

$$
t \quad=\text { waktu (s) }
$$

3) Frekuensi: Frekuensi merupakan jumlah banyaknya tegangan atau arus AC yang mencapai puncak positif pada gelombang sinusoidal dalam satu detik. Dengan kata lain, frekuensi menyatakan laju di mana tegangan atau arus AC terjadi. Satuan frekuensi adalah $\operatorname{Hertz}(\mathrm{Hz})$ [9]. Frekuensi listrik dapat ditulis dengan persamaan (5).

$$
f=\frac{1}{\mathrm{~T}}
$$

Keterangan:

$f=$ Frekuensi $(\mathrm{Hz})$

$T=$ Periode dalam satu detik (s)

4) Daya: Daya merupakan jumlah energi listrik yang diserap dalam suatu sistem tenaga listrik. Daya pada sistem tegangan bolak-balik (AC) dikenal dengan tiga macam yaitu daya semu $(S)$, daya aktif $(P)$, dan daya reaktif $(Q)$. Hubungan antara daya semu $(S)$, daya aktif $(P)$, dan daya reaktif $(Q)$ dikenal dengan istilah segitiga daya. Hubungan antara ketiga fasa dapat dilihat pada Gambar 1.

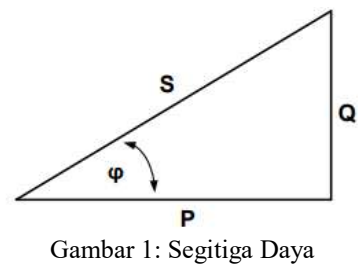

Pada penelitian ini jenis daya yang diukur adalah daya aktif atau daya nyata, daya aktif merupakan daya yang dikonsumsi oleh beban resistif murni. Satuan dari daya aktif adalah watt (W) [10]. Daya aktif dapat dituliskan dengan persamaan (6).

$$
P=V \times I \times \operatorname{Cos} \varphi
$$

Keterangan:

$P=$ Daya aktif $($ Watt $)$

$V=$ Tegangan (Volt)

$I=$ Arus listrik (Ampere)

$\operatorname{Cos} \varphi=$ Faktor Daya

Pada pengukuran daya listrik untuk sistem tiga fasa terdapat dua metode untuk mengukur daya listrik yaitu menggunakan dua buah wattmeter dan tiga buah wattmeter [8]. Total daya listrik tiga fasa menggunakan metode tiga buah wattmeter dapat dituliskan dengan persamaan (7).

$$
P=P_{R}+P_{S}+P_{T}
$$

5) Faktor Daya: Faktor daya atau disebut power factor merupakan perbandingan antara daya aktif (watt) dengan daya semu (VA). Cara lain untuk mewakili jumlah daya nyata ke daya reaktif dalam rangkaian listrik menggunakan faktor daya, yang dinyatakan dengan $\cos \varphi[11]$. Faktor daya dapat dituliskan dengan persamaan (8).

$$
P F=\frac{P}{S}=\frac{V \cdot I \cdot \cos \varphi}{V \cdot I}=\cos \varphi
$$

Aditya Pratama: Rancang Bangun Sistem Monitoring...
Keterangan:

$P F=$ Power Factor

$P=$ Daya Aktif (Watt)

$S=$ Daya Semu (VA)

\section{B. Wireless Sensor Network (WSN)}

Wireless sensor network (WSN) merupakan sebuah jaringan komunikasi wireless yang memungkinkan interaksi antara manusia dengan perangkat, terdiri dari beberapa node sensor yang diletakkan secara acak maupun manual pada area. Jaringan WSN diterapkan untuk memudahkan manusia dalam mengumpulkan informasi dari sebuah area yang sulit dijangkau [12]. Secara umum WSN dibagi menjadi dua bagian yaitu perangkat node sensor dan gateway yang terhubung dan berkomunikasi secara wireless. Setiap node pada WSN tersusun dari beberapa sensor, mikrokontroler, perangkat radio transceiver untuk komunikasi secara wireless dan sumber daya atau penyimpanan energi biasanya dalam bentuk baterai sebagai power supply.

\section{Perangkat Keras (Hardware)}

1) PZEM-004T: PZEM-004T merupakan sebuah modul elektronika yang berfungsi mengukur tegangan rms, arus rms, frekuensi, daya aktif, faktor daya, dan energi listrik. Modul PZEM-004T dapat terhubung dengan mikrokontroler maupun platform open source lainnya [13]. Tampilan dari modul PZEM-004T dapat dilihat pada Gambar 2.

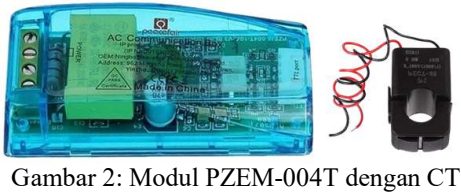

Untuk membaca hasil pengukuran modul PZEM-004T ini diperlukan mikrokontroler, karena modul PZEM-004T ini tidak dilengkapi dengan tampilan. Komunikasi data antara PZEM004T dengan mikrokontroler menggunakan interface TTL. Pada modul PZEM-004T dilengkapi current transformer (CT) yang dapat mengukur arus hingga 100A. Prinsip kerja CT pada modul PZEM-004T memanfaatkan medan magnet yang mengalir melalui cincin toroid. CT terdiri dari kumparan sekunder dan kumparan primer. Medan magnet akan mengalir dari kumparan primer ke kumparan sekunder menghasilkan arus listrik [14].

2) Arduino Nano: Arduino Nano merupakan modul mikrokontroler yang bersifat open source. Arduino Nano menggunakan mikrokontroler ATmega 328. Arduino Nano memiliki pin digital sebanyak empat belas pin yang memiliki fungsi bisa sebagai input maupun output, serta delapan pin input analog. Arduino Nano menggunakan bahasa pemrograman bahasa $\mathrm{C}$, bahasa yang mudah untuk menggunakan fungsi-fungsi yang sederhana, sehingga sangat mudah untuk mempelajari Arduino [15]. Gambar 3 menunjukan tampilan dari modul Arduino Nano.

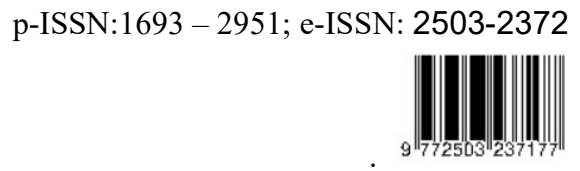




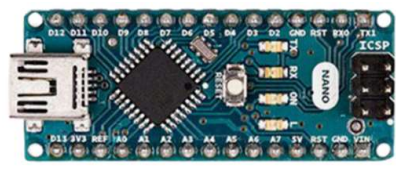

Gambar 3: Arduino Nano

3) LoRa (Long Range): LoRa merupakan singkatan dari long range yang berarti jarak jauh. Perangkat LoRa berkomunikasi secara nirkabel dengan memanfaatkan frekuensi sebagai media perantara untuk mengirimkan data. Perangkat LoRa menjadi salah satu perangkat transceiver yang unggul dalam jarak jangkauan yang luas, konsumsi daya yang rendah, serta tahan terhadap intervensi. Saat ini teknologi LoRa telah digunakan pada jaringan IoT di seluruh dunia. Perangkat LoRa telah banyak digunakan pada smart city, pertanian, smart home, pengukuran cerdas, dan lain sebagainya [16]. LoRa yang digunakan pada rancangan sistem monitoring listrik tiga fasa ini adalah LoRa Ra-02 SX1278 yang memiliki rentang frekuensi $433 \mathrm{MHz}$ yang dilengkapi dengan antena $3 \mathrm{dBi}$. Tampilan perangkat LoRa SX1278 dapat dilihat pada Gambar 4.

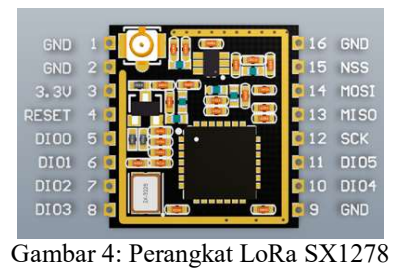

4) Mikrokontroler ESP32: ESP32 adalah generasi paling baru dari mikrokontroler pendahulunya yaitu ESP8266. Mikrokontroler ESP32 berisikan modul WiFi dan bluetooth, sehingga sangat cocok untuk mendukung penerapan jaringan Internet of Things (IoT) secara wireless [17]. Tampilan dari ESP32 dalam modul NodeMCU ESP32 dapat dilihat pada Gambar 5.

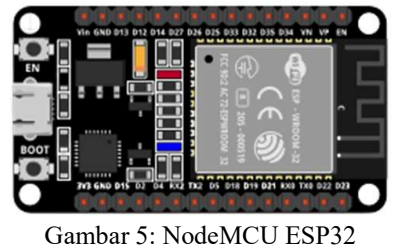

5) Modul RTC DS3231: Modul Real Time Clock merupakan modul yang berfungsi untuk menyimpan data waktu dan tanggal digital yang dapat diakses dari mikrokontroler [18]. Modul ini menggunakan chip DS3231 dengan protokol komunikasi I2C yang dapat menyimpan data detik, menit, jam, tanggal, bulan, hari dengan tingkat akurasi yang tinggi. Tampilan dari RTC DS3231 dapat dilihat pada Gambar 6.

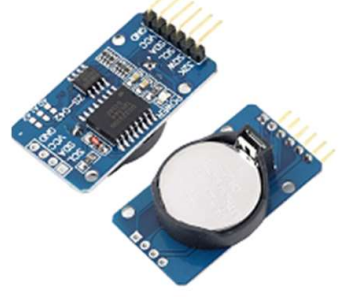

Gambar 6: Modul RTC DS3231

6) Modul Mikro SD Card: Modul yang digunakan untuk menuliskan data ke dalam memori mikro SD card melalui komunikasi SPI. Agar dapat melakukan read dan write pada mikro SD card modul ini dilengkapi dengan MCU. Modul mikro SD card memiliki enam buah pin yaitu (GND, VCC, MISO, MOSI, SCK, dan CS) [18]. Tampilan dari modul mikro SD card dapat dilihat pada Gambar 7.

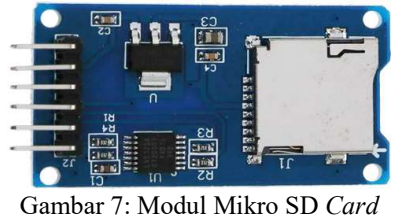

7) Buzzer: Buzzer merupakan sebuah komponen yang dapat mengkonversi sinyal listrik menjadi getaran berupa suara. Komponen buzzer dapat dimanfaatkan sebagai alarm dengan memberikan tegangan pada pin input buzzer [19]. Pada penelitian ini buzzer digunakan sebagai alarm notifikasi ketika node receiver tidak terhubung dengan jaringan $\mathrm{WiFi}$. Tampilan dari komponen buzzer dapat dilihat pada Gambar 8 .

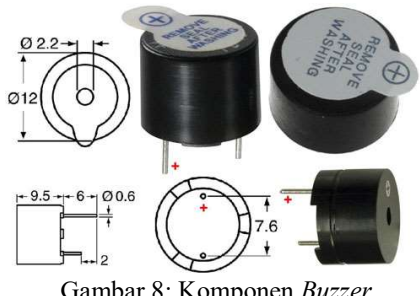

\section{Perangkat Lunak (Software)}

1) XAMPP: XAMPP merupakan perangkat lunak open source yang digunakan sebagai server yang berdiri sendiri pada komputer. Aplikasi XAMPP terdiri dari program Apache HTTP server, MySQL database, dan penerjemah bahasa pemrograman PHP dan perl [20]. Pada penelitian ini aplikasi XAMPP ini di-instal pada laptop atau komputer yang digunakan dengan hidupkan program apache maka perangkat laptop ataupun komputer akan menjadi server yang berdiri sendiri atau disebut localhost. Untuk menyimpan data monitoring listrik ke dalam database MySQL secara online, NodeMCU ESP32 perlu terhubung dengan komputer server localhost ini. Database MySQL yang digunakan adalah database yang terdapat pada aplikasi XAMPP.

\section{METODE PENELITIAN}

ISSN $1693-2951$ 
Pemodelan sistem monitoring listrik yang dirancang terdiri dari pemodelan perangkat keras dan pemodelan perangkat lunak. Pemodelan sistem monitoring listrik tiga fasa pada penelitian ini ditunjukan pada Gambar 9.

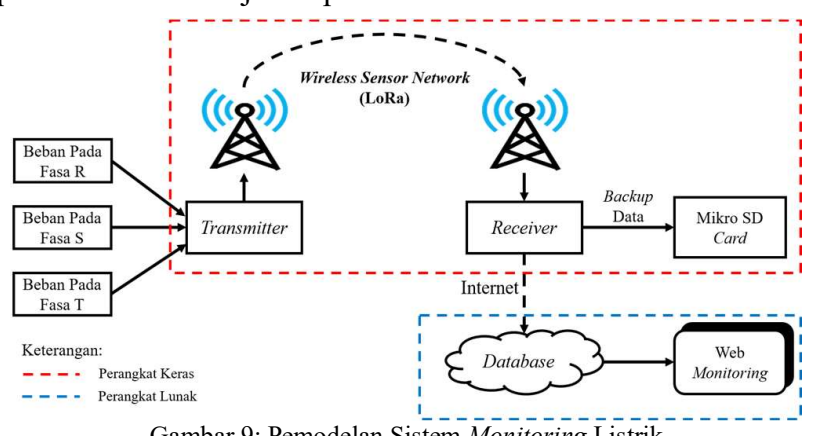

Gambar 9: Pemodelan Sistem Monitoring Listrik

1) Perangkat Keras: Pada pemodelan perangkat keras, sistem monitoring dibagi menjadi dua yaitu node transmitter dan node receiver. Node transmitter bertugas untuk melakukan pembacaan besaran listrik tegangan, arus listrik, frekuensi, faktor daya, dan daya aktif dari sistem tiga fasa pada panel listrik, kemudian mengirimkan data tersebut ke node receiver menggunakan transmisi LoRa. Node receiver bertugas sebagai gateway yang akan menerima data dari node transmitter, kemudian meneruskan data tersebut ke komputer server dan disimpan pada database dalam kondisi node receiver terhubung dengan koneksi internet yaitu WiFi. Jika node receiver tidak dapat terhubung dengan jaringan internet maka data akan secara otomatis disimpan pada mikro SD card dan akan kembali disimpan pada database ketika sudah terhubung kembali dengan koneksi WiFi. Penyimpanan pada mikro SD card disini hanya sebagai penyimpanan cadangan sementara ketika jaringan WiFi tidak dapat terkoneksi dengan node receiver.

2) Perangkat Lunak: Pada pemodelan perangkat lunak berfokus pada visualisasi data yang telah disimpan pada database oleh node receiver. Data yang telah tersimpan pada database nantinya akan ditampilkan secara online pada sebuah web monitoring. Pada web monitoring tersebut terdapat menu pilih untuk menampilkan data dalam bentuk tabel yang datanya bisa di-export, maupun live grafik dari masing-masing besaran listrik.

\section{B. Perancangan Perangkat Keras}

1) Node Transmitter: Pada node transmitter perancangan perangkat keras perancangan rangkaian modul PZEM-004T untuk membaca besaran listrik dan khusus pada pembacaan arus listrik menggunakan current transformer (CT), di mana setiap satu modul PZEM-004T bertugas untuk membaca besaran listrik pada satu fasa. Pada node transmitter menggunakan mikrokontroler ATmega 328 dengan modul Arduino Nano sebagai pengolah data pembacaan besaran listrik Aditya Pratama: Rancang Bangun Sistem Monitoring...

dari ketiga modul PZEM-004T. Modul PZEM-004T dengan Arduino Nano terhubung menggunakan komunikasi serial UART (Universal Asynchronous Receiver-Transmitter). LoRa Ra-02 SX1278 digunakan untuk mengirimkan data dari Arduino Nano ke NodeMCU ESP32 pada node receiver menggunakan transmisi radio dengan frekuensi 433MHz. Node transmitter juga dilengkapi dengan display LCD 20x4 untuk menampilkan informasi nilai besaran listrik yang terbaca pada PZEM-004T. Untuk sumber tegangan pada Arduino Nano 5V DC diperoleh dari buck converter dengan kapasitas arus $700 \mathrm{~mA}$. Wiring diagram rangkaian sistem pada node transmitter dapat dilihat pada Gambar 10.

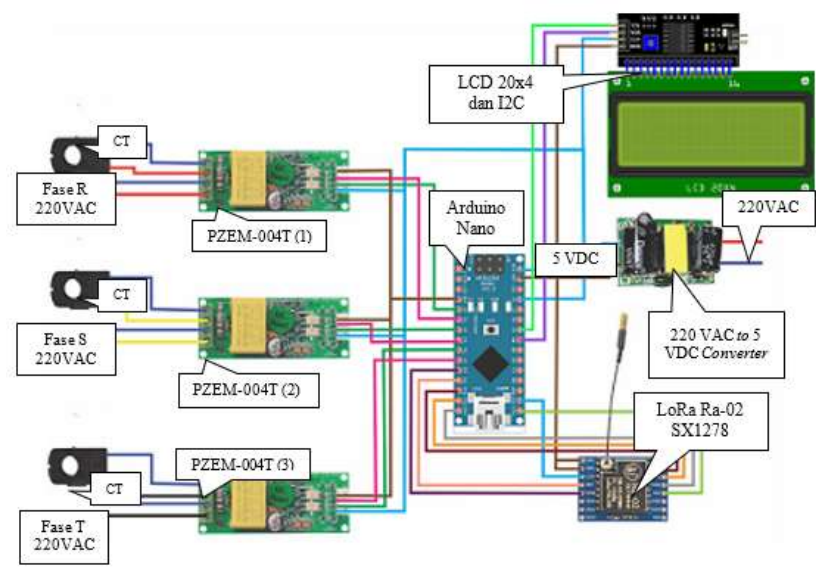

Gambar 10: Wiring Diagram dari Node Transmitter

2) Node Receiver: Perancangan perangkat keras pada node receiver menggunakan mikrokontroler ESP32 dengan modul NodeMCU ESP32 sebagai pengolah data utama pada node receiver, NodeMCU ESP32 yang bertugas untuk mengirimkan data ke komputer server ketika terkoneksi dengan $\mathrm{WiFi}$ ataupun mengirim data ke penyimpan cadangan mikro SD card melalui Arduino Nano. Sama halnya dengan node transmitter pada node receiver menggunakan LoRa Ra-02 SX1278 untuk menerima data dari node transmitter yang dikirimkan menggunakan transmisi wireless. Terdapat display LCD 16x2 untuk menampilkan informasi status data yang masuk ke NodeMCU ESP32 dan informasi apakah NodeMCU ESP32 terkoneksi dengan $\mathrm{WiFi}$ atau tidak. Sesuai dengan pemodelan yang dilakukan ketika NodeMCU ESP32 tidak terkoneksi dengan WiFi maka data akan secara otomatis disimpan pada mikro SD card. Sistem penyimpanan cadangan ini tersusun dari Arduino Nano sebagai pengolah data, modul mikro SD card untuk read dan write pada memori mikro SD card, modul RTC digunakan untuk mencatat waktu dan tanggal saat data dituliskan pada mikro SD card. Penambahan komponen buzzer berguna untuk memberi alarm dalam bentuk suara ketika NodeMCU ESP32 tidak terkoneksi WiFi. Keseluruhan sistem dari node receiver ini disuplai dari adaptor $5 \mathrm{~V}$ dengan kapasitas arus $600 \mathrm{~mA}$. Yang terhubung dengan input tegangan pada NodeMCU ESP32 dan Arduino Nano. Wiring diagram

p-ISSN:1693 - 2951; e-ISSN: 2503-2372 
rangkaian sistem pada node receiver dapat dilihat pada Gambar 11.

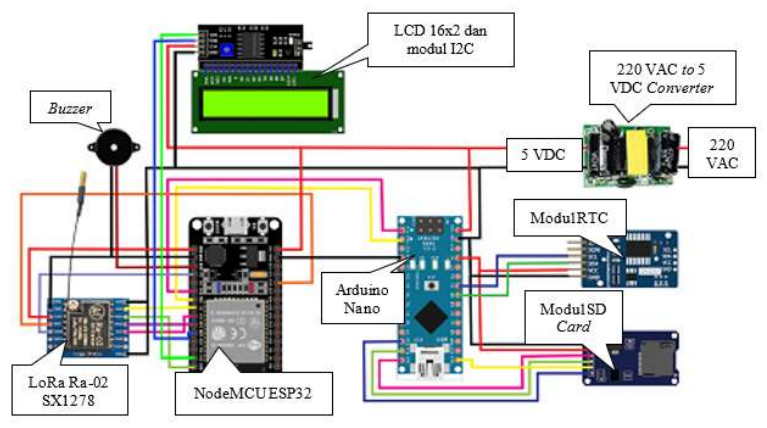

Gambar 11: Wiring Diagram dari Node Receiver

\section{Perancangan Perangkat Lunak}

Perancangan perangkat lunak untuk tampilan web monitoring pada rancang bangun monitoring listrik merupakan rancangan program untuk menampilkan data tegangan, arus listrik, frekuensi, faktor daya, dan daya aktif yang tersimpan pada database MySQL guna memudahkan pengguna dalam mengakses data besaran listrik. Web monitoring akan dirancang akan menampilkan besaran listrik dalam bentuk tabel lengkap dengan informasi waktu dan tanggal data disimpan, kemudian terdapat live grafik untuk setiap besaran listrik. Pada perancangan perangkat lunak ini juga menggunakan aplikasi XAMPP yang sudah dipasangkan pada komputer atau laptop sebagai web server. Aplikasi XAMPP juga telah terdapat database MySQL. Pada Gambar 12 menunjukan diagram alir proses kerja web monitoring.
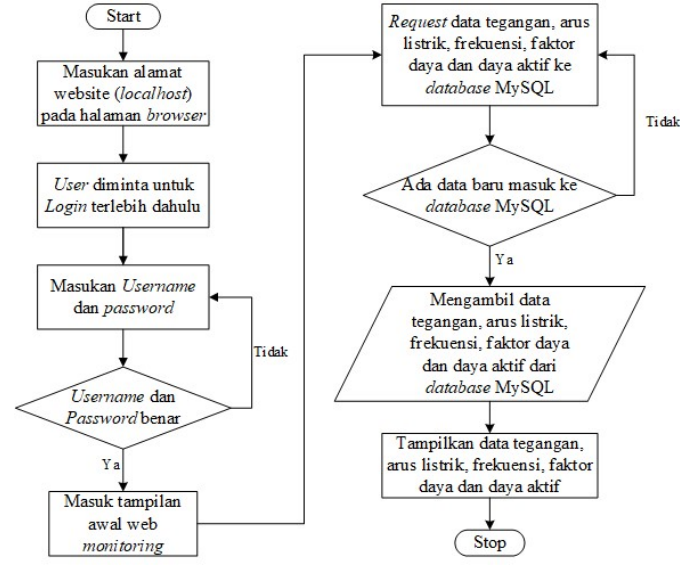

Gambar 12: Diagram Alir Visualisasi Data pada Web Monitoring

\section{HASIL DAN PEMBAHASAN}

\section{A. Realisasi Hasil Perancangan Sistem}

Hasil realisasi dari rancangan alat monitoring sistem listrik tiga fasa berbasis wireless sensor network menggunakan LoRa Ra-02 SX1278 ditunjukan pada Gambar 13. Sebelah kiri merupakan hasil rancangan dari node transmitter dan sebelah kanan merupakan hasil realisasi dari rancangan node receiver.

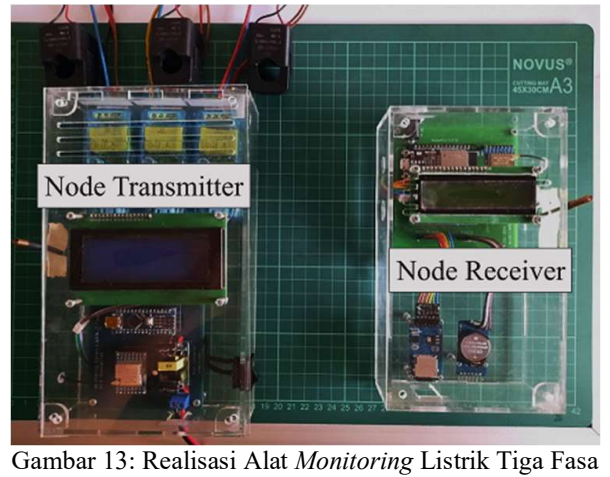

\section{B. Pengujian Catu Daya}

Catu daya yang digunakan dalam pengoperasian alat monitoring listrik tiga fasa berbasis wireless sensor network ini adalah buck converter $5 \mathrm{~V}$ dengan kapasitas arus $700 \mathrm{~mA}$ sebagai suplai tegangan dari Arduino Nano pada node transmitter, serta menggunakan adaptor $5 \mathrm{~V}$ dengan kapasitas 600mA sebagai suplai NodeMCU ESP32 dan Arduino Nano pada node receiver.

1) Pengujian Rangkaian Power Supply Tanpa Beban: Pada pengujian rangkaian tanpa beban diperoleh hasil pengukuran tegangan pada rangkaian node transmitter diperoleh nilai $5,026 \mathrm{~V}$ dan hasil pengukuran tegangan pada rangkaian node receiver diperoleh nilai $5,109 \mathrm{~V}$. Hasil pengujian ini menunjukan bahwa tegangan input telah sesuai dengan desain dan siap disalurkan ke rangkaian karena sudah sesuai dengan tegangan kerja.

2) Pengujian Rangkaian Power Supply dengan Beban: Pada pengujian rangkaian dengan beban diperoleh hasil pengukuran penggunaan arus pada node transmitter sebesar 29,33mA, sedangkan pada pengukuran nilai penggunaan arus pada node receiver diperoleh sebesar $84,60 \mathrm{~mA}$. Dari hasil pengujian ini menunjukan bahwa penggunaan arus pada setiap rangkaian masih jauh dibawah kapasitas arus maksimal yang dapat disuplai baik oleh buck converter maupun adaptor.

\section{Pengujian Modul PZEM-004T}

Pengujian rangkaian modul PZEM-004T memiliki tujuan untuk mengetahui tingkat presisi dari pembacaan parameter dari listrik Alternating Current (AC) pada modul PZEM-004T. parameter listrik yang akan diuji terdiri dari tegangan, arus listrik, frekuensi, faktor daya, dan daya aktif. Pengujian akan dilakukan sebanyak lima kali pengukuran.

1) Pengukuran Tegangan: Pada pengukuran nilai tegangan bertujuan untuk membandingkan hasil pembacaan nilai tegangan bolak-balik pada modul PZEM-004T dengan pembacaan alat ukur AVOmeter digital KW06-769. Pada Tabel I menunjukkan hasil pengujian pengukuran tegangan.

TABEL I

Hasil PembacaAn Nilai TEgangan Pada Modul PZEM-004T

\begin{tabular}{|c|c|c|c|c|c|}
\hline \multirow{2}{*}{$\begin{array}{c}\text { Pengujian } \\
\text { Ke- }\end{array}$} & \multicolumn{2}{|c|}{ Hasil Pengukuran (V) } & \multirow{2}{*}{$\begin{array}{c}\text { Error } \\
\text { nelo }\end{array}$} & $\begin{array}{c}\text { Rata-Rata } \\
\text { Error }(\%)\end{array}$ \\
\hline 1. & $\mathrm{R}$ & 231,3 & 231,0 & 0,13 & 0,13 \\
\hline
\end{tabular}

ISSN $1693-2951$ 
Majalah Ilmiah Teknologi Elektro, Vol. 20, No.2, Juli-Desember 2021

DOI: https://doi.org/10.24843/MITE.2021.v20i02.P20

\begin{tabular}{|c|c|c|c|c|c|}
\hline & $\mathrm{S}$ & 236,1 & 235,7 & 0,17 & \\
\hline & $\mathrm{T}$ & 232,7 & 232,9 & 0,09 & \\
\hline \multirow{3}{*}{2.} & $\mathrm{R}$ & 231,3 & 231,2 & 0,05 & \multirow{3}{*}{0,09} \\
\hline & $\mathrm{S}$ & 235,9 & 235,7 & 0,09 & \\
\hline & $\mathrm{T}$ & 233,0 & 233,3 & 0,13 & \\
\hline \multirow{3}{*}{3.} & $\mathrm{R}$ & 232,1 & 231,9 & 0,09 & \multirow{3}{*}{0,12} \\
\hline & $\mathrm{S}$ & 236,0 & 235,7 & 0,13 & \\
\hline & $\mathrm{T}$ & 233,8 & 234,1 & 0,13 & \\
\hline \multirow{3}{*}{4.} & $\mathrm{R}$ & 232,5 & 232,3 & 0,09 & \multirow{3}{*}{0,12} \\
\hline & $\mathrm{S}$ & 236,1 & 235,7 & 0,17 & \\
\hline & $\mathrm{T}$ & 234,0 & 234,2 & 0,09 & \\
\hline \multirow{3}{*}{5.} & $\mathrm{R}$ & 231,9 & 231,7 & 0,09 & \multirow{3}{*}{0,10} \\
\hline & $\mathrm{S}$ & 236,0 & 235,7 & 0,13 & \\
\hline & $\mathrm{T}$ & 233,9 & 234,1 & 0,09 & \\
\hline \multicolumn{5}{|c|}{ Rata-Rata Error Keseluruhan } & 0.11 \\
\hline
\end{tabular}

pengukuran frekuensi listrik pada modul PZEM-004T dan alat ukur AVOmeter digital KW06-769 dapat dilihat pada Tabel III.

TABEL III

Hasil PEMBaCAAN Nilai FreKUENSI PADA Modul PZEM-004T

\begin{tabular}{|c|c|c|c|c|c|}
\hline \multirow{2}{*}{\multicolumn{2}{|c|}{$\begin{array}{c}\text { Pengujian } \\
\text { Ke- }\end{array}$}} & \multicolumn{2}{|c|}{ Hasil Pengukuran (Hz) } & \multirow{3}{*}{$\begin{array}{c}\begin{array}{c}\text { Error } \\
(\%)\end{array} \\
0,02 \\
\end{array}$} & \multirow{2}{*}{$\begin{array}{l}\text { Rata-Rata } \\
\text { Error (\%) }\end{array}$} \\
\hline & & \multirow{2}{*}{$\begin{array}{c}\text { PZEM-004T } \\
50,00 \\
\end{array}$} & \multirow{2}{*}{$\begin{array}{c}\text { AVOmeter } \\
50,01\end{array}$} & & \\
\hline \multirow{3}{*}{1.} & $\mathrm{R}$ & & & & \multirow{3}{*}{0,01} \\
\hline & $\mathrm{S}$ & 50,00 & 50,00 & 0,00 & \\
\hline & $\mathrm{T}$ & 50,00 & 50,00 & 0,00 & \\
\hline \multirow{3}{*}{2.} & $\mathrm{R}$ & 50,00 & 50,01 & 0,02 & \multirow{3}{*}{0,02} \\
\hline & $\mathrm{S}$ & 50,00 & 50,01 & 0,02 & \\
\hline & $\mathrm{T}$ & 50,00 & 50,01 & 0,02 & \\
\hline \multirow{3}{*}{3.} & $\mathrm{R}$ & 49,90 & 49,92 & 0,04 & \multirow{3}{*}{0,04} \\
\hline & $\mathrm{S}$ & 49,90 & 49,92 & 0,04 & \\
\hline & $\mathrm{T}$ & 49,90 & 49,92 & 0,04 & \\
\hline \multirow{3}{*}{4.} & $\mathrm{R}$ & 50,00 & 50,00 & 0,00 & \multirow{3}{*}{0} \\
\hline & $\mathrm{S}$ & 50,00 & 50,00 & 0,00 & \\
\hline & $\mathrm{T}$ & 50,00 & 50,00 & 0,00 & \\
\hline \multirow{3}{*}{5.} & $\mathrm{R}$ & 50,00 & 50,02 & 0,04 & \multirow{3}{*}{0,04} \\
\hline & $\mathrm{S}$ & 50,00 & 50,02 & 0,04 & \\
\hline & $\mathrm{T}$ & 50,00 & 50,02 & 0,04 & \\
\hline \multicolumn{5}{|c|}{ Rata-Rata Error Keseluruhan } & 0,02 \\
\hline
\end{tabular}

Berdasarkan hasil pengujian pembacaan nilai frekuensi listrik pada Tabel III, diperoleh nilai rata-rata error pembacaan modul PZEM-004T secara keseluruhan sebesar 0,02\%.

Hasil PembacaAn Nilai ARUs Listrik PADA Modul PZEM-004T

\begin{tabular}{|c|c|c|c|c|c|c|}
\hline \multirow{2}{*}{\multicolumn{2}{|c|}{$\begin{array}{c}\text { Pengujian } \\
\mathrm{Ke}-\end{array}$}} & \multirow{3}{*}{$\begin{array}{l}\text { Beban } \\
60 \mathrm{~W}\end{array}$} & \multicolumn{2}{|c|}{ Hasil Pengukuran (A) } & \multirow{3}{*}{$\begin{array}{c}\begin{array}{c}\text { Error } \\
(\%)\end{array} \\
2,27 \\
\end{array}$} & \multirow{2}{*}{$\begin{array}{c}\text { Rata- } \\
\text { Rata } \\
\text { Error } \\
(\%) \\
\end{array}$} \\
\hline & & & \multirow{2}{*}{$\begin{array}{c}\text { PZEM- } \\
004 \mathrm{~T} \\
0,270 \\
\end{array}$} & \multirow{2}{*}{$\begin{array}{c}\text { AVOmeter } \\
0,264\end{array}$} & & \\
\hline \multirow{3}{*}{1.} & $\mathrm{R}$ & & & & & \multirow{3}{*}{1,29} \\
\hline & $\mathrm{S}$ & $65 \mathrm{~W}$ & 0,300 & 0,300 & 0 & \\
\hline & $\mathrm{T}$ & $40 \mathrm{~W}$ & 0,190 & 0,187 & 1,60 & \\
\hline \multirow{3}{*}{2.} & $\mathrm{R}$ & $40 \mathrm{~W}$ & 0,180 & 0,178 & 1,12 & \multirow{3}{*}{0,98} \\
\hline & $\mathrm{S}$ & $75 \mathrm{~W}$ & 0,340 & 0,340 & 0 & \\
\hline & $\mathrm{T}$ & $85 \mathrm{~W}$ & 0,390 & 0,383 & 1,82 & \\
\hline \multirow{3}{*}{3.} & $\mathrm{R}$ & $15 \mathrm{~W}$ & 0,080 & 0,074 & 8,10 & \multirow{3}{*}{3,22} \\
\hline & $\mathrm{S}$ & $60 \mathrm{~W}$ & 0,270 & 0,268 & 0,74 & \\
\hline & $\mathrm{T}$ & $25 \mathrm{~W}$ & 0,120 & 0,121 & 0,82 & \\
\hline \multirow{3}{*}{4.} & $\mathrm{R}$ & $125 \mathrm{~W}$ & 0,550 & 0,550 & 0 & \multirow{3}{*}{2,04} \\
\hline & $\mathrm{S}$ & $15 \mathrm{~W}$ & 0,080 & 0,076 & 5,26 & \\
\hline & $\mathrm{T}$ & $50 \mathrm{~W}$ & 0,230 & 0,228 & 0,87 & \\
\hline \multirow{3}{*}{5.} & $\mathrm{R}$ & $50 \mathrm{~W}$ & 0,220 & 0,220 & 0 & \multirow{3}{*}{3,05} \\
\hline & $\mathrm{S}$ & $125 \mathrm{~W}$ & 0,570 & 0,564 & 1,06 & \\
\hline & $\mathrm{T}$ & $15 \mathrm{~W}$ & 0,080 & 0,074 & 8,10 & \\
\hline
\end{tabular}

Berdasarkan hasil pengujian pembacaan nilai arus listrik pada Tabel II, diperoleh nilai rata-rata error pembacaan modul PZEM-004T secara keseluruhan sebesar 2,11\%.

3) Pengukuran Frekuensi Listrik: Pada pengukuran nilai frekuensi listrik bertujuan untuk membandingkan hasil pembacaan nilai frekuensi listrik pada modul PZEM-004T dengan alat ukur AVOmeter digital KW06-769. Pada pengujian frekuensi listrik menggunakan tiga buah AVOmeter, untuk setiap fasa menggunakan satu buah AVOmeter. Hasil pengujian

Aditya Pratama: Rancang Bangun Sistem Monitoring...

4) Pengukuran Faktor Daya: Pada pengukuran nilai faktor daya bertujuan untuk membandingkan hasil pembacaan nilai faktor daya atau cos phi pada modul PZEM-004T dengan alat ukur multimeter digital Lucas Nulle CO5127-1Z. Pada pengujian pengukuran faktor daya ini beban listrik yang digunakan adalah lampu pijar untuk setiap satu kali pengukuran menggunakan beban seimbang yaitu beban pada fasa $\mathrm{R}, \mathrm{S}$, dan $\mathrm{T}$ sama besarnya. Penggunaan beban yang seimbang bertujuan untuk menghindari perubahan sudut fasa pada sistem listrik tiga fasa saat pengambilan nilai faktor daya. Hasil pengujian pengukuran faktor daya pada modul PZEM-004T dengan alat ukur multimeter digital Lucas Nulle CO5127-1Z dapat dilihat pada Tabel IV.

TABEL IV

Hasil Pembacaan Nilai Faktor Daya pada Modul PZEM-004T

\begin{tabular}{|c|c|c|c|c|c|c|}
\hline \multirow{2}{*}{\multicolumn{2}{|c|}{$\begin{array}{c}\text { Pengujian } \\
\text { Ke- }\end{array}$}} & \multirow{2}{*}{ Beban } & \multicolumn{2}{|c|}{ Hasil Pengukuran } & \multirow{2}{*}{$\begin{array}{c}\text { Error } \\
(\%)\end{array}$} & \multirow{2}{*}{$\begin{array}{l}\text { Rata-Rata } \\
\text { Error }(\%)\end{array}$} \\
\hline & & & $\begin{array}{c}\text { PZEM- } \\
004 T\end{array}$ & Multimeter & & \\
\hline \multirow{3}{*}{1.} & $\mathrm{R}$ & \multirow{3}{*}{$40 \mathrm{~W}$} & 0,97 & 0,96 & 1,04 & \multirow{3}{*}{1,04} \\
\hline & $\mathrm{S}$ & & 0,97 & 0,96 & 1,04 & \\
\hline & $\mathrm{T}$ & & 0,97 & 0,96 & 1,04 & \\
\hline \multirow{3}{*}{2.} & $\mathrm{R}$ & \multirow{3}{*}{$65 \mathrm{~W}$} & 0,98 & 0,98 & 0 & \multirow{3}{*}{0,34} \\
\hline & $\mathrm{S}$ & & 0,98 & 0,98 & 0 & \\
\hline & $\mathrm{T}$ & & 0,99 & 0,98 & 1,02 & \\
\hline \multirow{3}{*}{3.} & $\mathrm{R}$ & \multirow{3}{*}{$100 \mathrm{~W}$} & 0,99 & 0,99 & 0 & \multirow{3}{*}{0} \\
\hline & $\mathrm{S}$ & & 0,99 & 0,99 & 0 & \\
\hline & $\mathrm{T}$ & & 0,99 & 0,99 & 0 & \\
\hline
\end{tabular}

p-ISSN:1693 - 2951; e-ISSN: 2503-2372 


\begin{tabular}{|c|c|c|c|c|c|c|}
\hline \multirow{3}{*}{4.} & $\mathrm{R}$ & \multirow{3}{*}{$125 \mathrm{~W}$} & 0,99 & 0,99 & 0 & \multirow{3}{*}{0} \\
\hline & $\mathrm{S}$ & & 0,99 & 0,99 & 0 & \\
\hline & $\mathrm{T}$ & & 0,99 & 0,99 & 0 & \\
\hline \multirow{3}{*}{5.} & $\mathrm{R}$ & \multirow{3}{*}{$15 \mathrm{~W}$} & 0,87 & 0,81 & 7,41 & \multirow{3}{*}{8,68} \\
\hline & $\mathrm{S}$ & & 0,88 & 0,81 & 8,64 & \\
\hline & $\mathrm{T}$ & & 0,88 & 0,80 & 10,00 & \\
\hline \multicolumn{6}{|c|}{ Rata-Rata Error Keseluruhan } & 2,01 \\
\hline
\end{tabular}

Berdasarkan hasil pengujian pembacaan nilai faktor daya pada Tabel IV, diperoleh nilai rata-rata error pembacaan modul PZEM-004T keseluruhan sebesar 2,01\%.

5) Pengukuran Daya Aktif: Pada pengukuran nilai daya aktif bertujuan untuk membandingkan hasil pembacaan nilai daya aktif pada modul PZEM-004T dengan alat ukur multimeter digital Lucas Nulle CO5127-1Z. Pada Tabel V menunjukkan hasil pengujian pengukuran daya aktif.

\section{TABEL V}

Hasil PembacAan Nilai Daya AKTIF PADA Modul PZEM-004T

\begin{tabular}{|c|c|c|c|c|c|c|}
\hline \multirow{2}{*}{\multicolumn{2}{|c|}{$\begin{array}{c}\text { Pengujian } \\
\text { Ke- }\end{array}$}} & \multirow{2}{*}{ Beban } & \multicolumn{2}{|c|}{ Hasil Pengukuran (W) } & \multirow{4}{*}{$\begin{array}{c}\text { Error } \\
(\%)\end{array}$} & \multirow{3}{*}{$\begin{array}{c}\text { Rata- } \\
\text { Rata } \\
\text { Error } \\
(\%)\end{array}$} \\
\hline & & & PZEM- & Multimeter & & \\
\hline \multirow{4}{*}{1.} & & \multirow{4}{*}{$40 \mathrm{~W}$} & & & & \\
\hline & $\mathrm{R}$ & & 40,8 & 41,0 & & \multirow{3}{*}{0,77} \\
\hline & $\mathrm{S}$ & & 43,9 & 44,2 & 0,67 & \\
\hline & $\mathrm{T}$ & & 43,4 & 42,9 & 1,16 & \\
\hline \multirow{3}{*}{2.} & $\mathrm{R}$ & \multirow{3}{*}{$65 \mathrm{~W}$} & 65,7 & 65,8 & 0,15 & \multirow{3}{*}{1,31} \\
\hline & $\mathrm{S}$ & & 69,9 & 68,9 & 1,45 & \\
\hline & $\mathrm{T}$ & & 69,5 & 67,9 & 2,35 & \\
\hline \multirow{3}{*}{3.} & $\mathrm{R}$ & \multirow{3}{*}{$100 \mathrm{~W}$} & 100,9 & 100,8 & 0,09 & \multirow{3}{*}{0,63} \\
\hline & $\mathrm{S}$ & & 105,9 & 104,8 & 1,04 & \\
\hline & $\mathrm{T}$ & & 105,9 & 105,1 & 0,76 & \\
\hline \multirow{3}{*}{4.} & $\mathrm{R}$ & \multirow{3}{*}{$125 \mathrm{~W}$} & 126,3 & 125,4 & 0,71 & \multirow{3}{*}{0,99} \\
\hline & $\mathrm{S}$ & & 131,9 & 130,3 & 1,22 & \\
\hline & $\mathrm{T}$ & & 132,3 & 130,9 & 1,06 & \\
\hline \multirow{3}{*}{5.} & $\mathrm{R}$ & \multirow{3}{*}{$15 \mathrm{~W}$} & 15,6 & 15,5 & 0,64 & \multirow{3}{*}{1,63} \\
\hline & $\mathrm{S}$ & & 16,9 & 16,7 & 1,19 & \\
\hline & $\mathrm{T}$ & & 16,8 & 16,3 & 3,06 & \\
\hline \multicolumn{6}{|c|}{ Rata-Rata Error Keseluruhan } & 1,06 \\
\hline
\end{tabular}

Berdasarkan hasil pengujian pembacaan daya aktif pada tabel V, diperoleh nilai rata-rata error pembacaan modul PZEM-004T keseluruhan sebesar 1,06\%. Setelah melakukan pengukuran besaran listrik menggunakan modul PZEM-004T, dan membandingkan hasil hasil pengukuran dengan alat ukur konvensional, maka dilakukan perhitungan error secara keseluruhan pada pembacaan modul PZEM-004T. Hasil perhitungan nilai error pembacaan modul PZEM-004T ditunjukkan pada Tabel VI.

TABEL VI

HASIl RATA-RATA ERROR KESELURUHAN

\begin{tabular}{|c|c|}
\hline Parameter yang dibandingkan & Nilai rata-rata error (\%) \\
\hline Tegangan & 0,11 \\
\hline Arus Listrik & 2,11 \\
\hline Frekuensi & 0,02 \\
\hline Faktor Daya & 2,01 \\
\hline Daya Aktif & 1,06 \\
\hline Nilai rata-rata error keseluruhan & 1,062 \\
\hline
\end{tabular}

Hasil perhitungan nilai rata-rata penyimpangan sensor PZEM-004T secara keseluruhan diperoleh sebesar 1,062\% $\approx$ $1,07 \%$. Hasil akhir perhitungan rata-rata error pada modul PZEM-004T menunjukan bahwa sesuai standar IEC No. 13B23, alat monitoring listrik tiga fasa menggunakan modul PZEM-004T ini dapat digolongkan ke dalam alat ukur kelas 1 dengan nilai penyimpangan $\pm 1,0 \%$. Alat monitoring listrik tiga fasa ini tergolong ke dalam alat ukur yang dapat diterapkan pada panel listrik maupun alat ukur portable.

\section{Pengujian Transmisi LoRa}

1) Transmisi Data LoRa pada Kondisi LOS (Line of Sight): Pengujian transmisi LoRa pada kondisi LOS (Line of Sight) bertujuan untuk mengetahui jarak maksimum pada keberhasilan transmisi data pada LoRa Ra-02 SX1278 menggunakan frekuensi $443 \mathrm{MHz}$ dan antena $3 \mathrm{dBi}$. Pengujian pada kondisi LOS ini dilakukan dengan mentransmisikan data antara dua node pada area yang benar-benar tidak terdapat halangan atau bebas pandang. Pengujian dilakukan pada area Waduk Muara Nusa Dua, Pemogan, Denpasar, Bali. Hasil pengujian dapat dilihat pada Gambar 14.

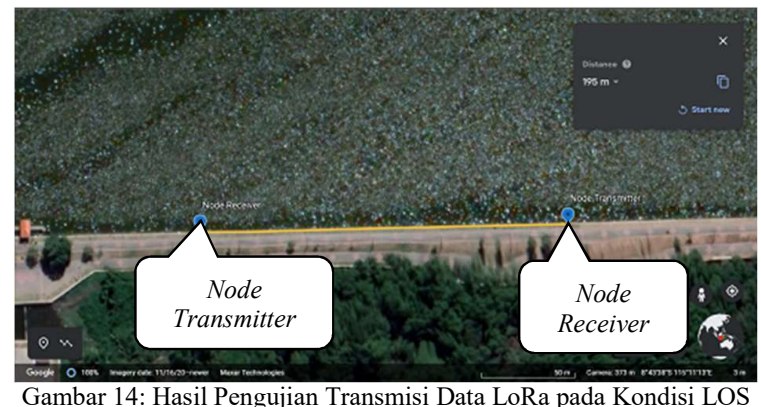

Hasil pengujian transmisi data dari node transmitter menuju node receiver yang dilakukan pada kondisi LOS ini diperoleh jarak maksimum transmisi data monitoring listrik sejauh 195 meter.

2) Transmisi Data LoRa pada Kondisi NLOS (Non Line of Sight): Pengujian transmisi LoRa pada kondisi NLOS (Line of Sight) dilakukan untuk mengetahui jarak maksimum pada keberhasilan transmisi data pada LoRa Ra-02 SX1278 menggunakan frekuensi $443 \mathrm{MHz}$ dan antena $3 \mathrm{dBi}$. Pengujian pada kondisi NLOS ini dilakukan dengan mentransmisikan sinyal pada jalur yang sebagian terhalang, biasanya oleh objek fisik seperti pohon dan bangunan. Pengujian dilakukan pada Fakultas Teknik Universitas Udayana, Bukit Jimbaran, Bali. Hasil pengujian transmisi data pada kondisi NLOS ditunjukan pada Gambar 15. 
DOI: https://doi.org/10.24843/MITE.2021.v20i02.P20

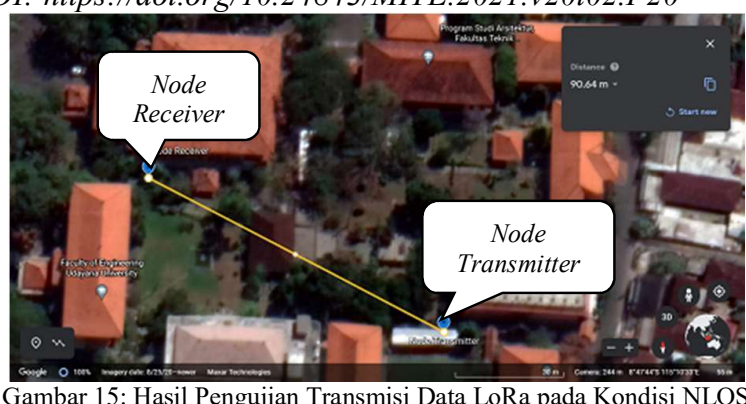

Hasil pengujian transmisi data dari node transmitter menuju node receiver yang dilakukan pada kondisi NLOS diperoleh jarak maksimum transmisi data monitoring listrik sejauh 90 meter.

3) Pengujian Pengaruh Jumlah Node Transmitter Terhadap Keberhasilan Transmisi Data: Pada pengujian ini bertujuan untuk mengetahui tingkat keberhasilan transmisi data antara menggunakan satu dan dua buah node transmitter. Pada transmisi data dua buah node transmitter, data dibedakan menggunakan ID untuk node 1 dan node 2 transmitter. Data yang ditransmisikan tidak dilakukan secara bersamaan untuk menghindari data yang bertabrakan saat diterima oleh node receiver. Jeda pengiriman data antara node 1 dan node 2 sebesar 10 detik. Pengujian dilakukan dengan jarak berdekatan sehingga perubahan kualitas pengiriman data tidak dipengaruhi oleh jarak dan hanya berfokus pada jumlah node transmitter yang terhubung.

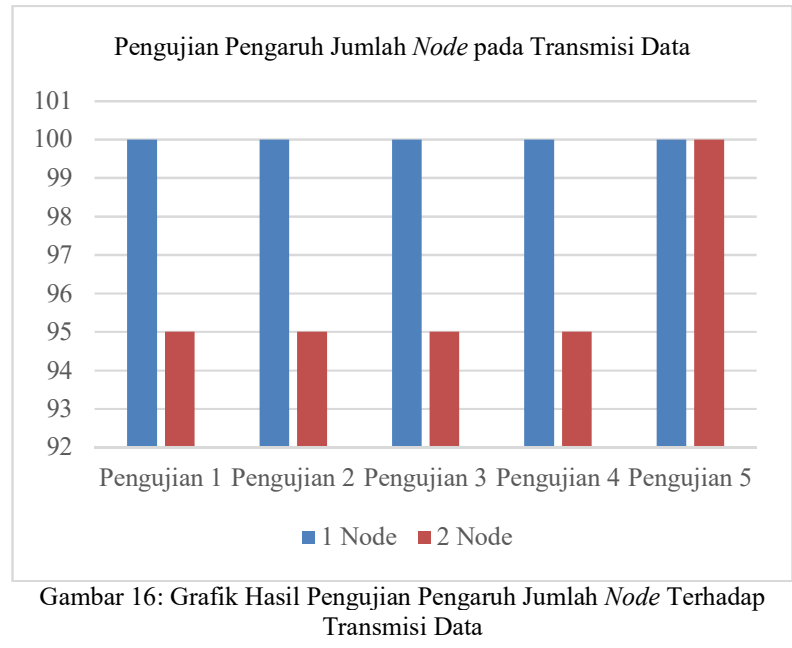

Dari hasil pengujian transmisi data, jumlah node transmitter yang digunakan mempengaruhi persentase keberhasilan transmisi data pada LoRa Ra-02 SX1278 pada pengujian menggunakan sebuah node transmitter memiliki rata-rata persentase keberhasilan transmisi data sebesar $100 \%$ pada seluruh pengujian yang dilakukan. Sedangkan pada pengujian menggunakan dua buah node transmitter memiliki rata-rata persentase keberhasilan transmisi data sebesar 96\% yang Aditya Pratama: Rancang Bangun Sistem Monitoring... menunjukan bahwa terdapat data loss saat pengiriman data dari node transmitter 1 dengan node transmitter 2 yang dikirimkan dengan jarak waktu 10 detik antar node transmitter menuju ke node receiver.

\section{E. Pengujian Menyimpan Data pada Mikro SD Card}

Pada pengujian penyimpanan pada mikro SD card bertujuan untuk mengetahui kemampuan alat monitoring listrik dalam melakukan backup data ketika NodeMCU ESP32 tidak terkoneksi dengan jaringan WiFi. Data tegangan, arus listrik, frekuensi, faktor daya, dan daya aktif. Disimpan pada mikro SD card dengan file yang bernama datalog.txt. Arduino Nano juga memberikan perintah kepada modul RTC DS3231 untuk memberikan data tanggal dan waktu ketika data dituliskan pada memori mikro SD card. Dari hasil pengujian yang dilakukan ketika NodeMCU ESP32 tidak terkoneksi $W i F i$ data berhasil disimpan pada mikro SD card, hasil penyimpanan data pada mikro SD card dapat dilihat pada Gambar 17.

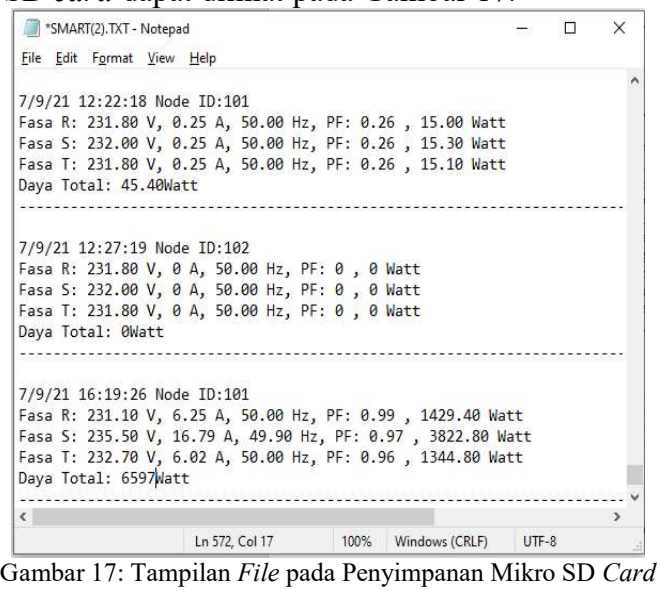

\section{F. Pengujian Visualisasi Data pada Web Monitoring}

Pada Pengujian visualisasi data pada web monitoring yang sudah dirancang, bertujuan untuk mengetahui data yang disimpan pada database dapat ditampilkan pada tampilan web monitoring sehingga memudahkan pengguna listrik dalam melakukan monitoring listrik. Pada pengujian yang dilakukan, web monitoring berhasil menampilkan data monitoring listrik dalam bentuk tabel yang dapat diubah bentuk dan disimpan ke dalam file pdf dan excel. Hasil pengujian dapat dilihat pada Gambar 18 .

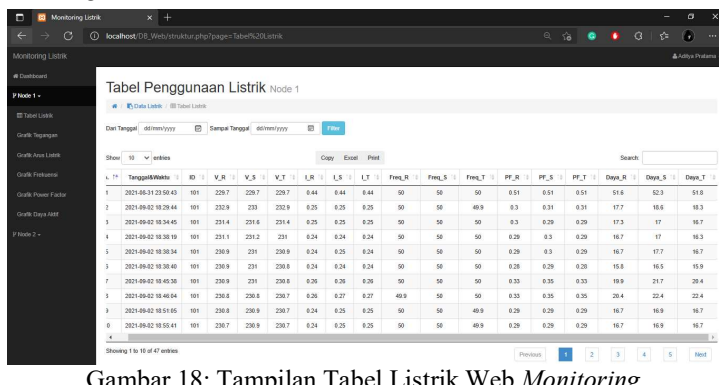

p-ISSN:1693 - 2951; e-ISSN: 2503-2372

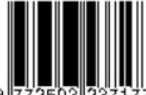


Web monitoring ini juga dilengkapi dengan grafik pada data monitoring listrik, grafik akan secara otomatis memperbaharui data ketika ada data yang masuk ke dalam database. Berikut merupakan tampilan dari salah satu grafik pada web monitoring yang ditunjukkan pada Gambar 19.

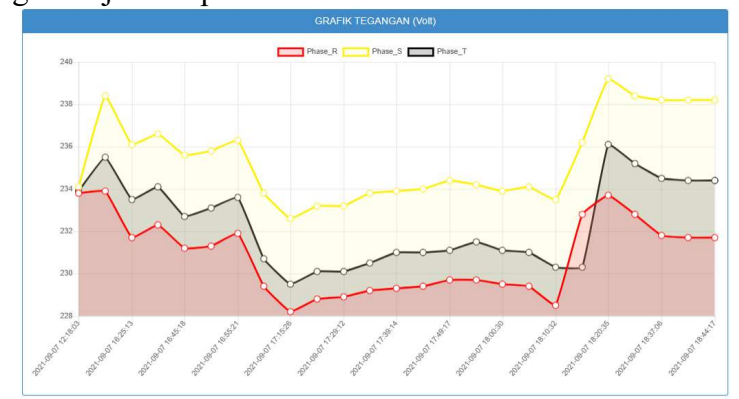

Gambar 19: Tampilan Grafik pada Web Monitoring

\section{KESIMPULAN}

Artikel ini telah merancang dan membangun sebuah sistem monitoring listrik tiga fasa berbasis wireless sensor network menggunakan LoRa Ra-02 SX1278 dan bagaimana kinerja dari alat monitoring listrik tersebut.

Hasil pengujian yang dilakukan menunjukkan bahwa alat monitoring listrik tiga fasa berbasis wireless sensor network menggunakan LoRa Ra-02 SX1278 berhasil dibangun. Seluruh perangkat keras dan perangkat lunak pada sistem dibangun bekerja sesuai dengan rancangan yang ditentukan. Kinerja dari alat monitoring listrik ini mampu melakukan membaca nilai tegangan, arus listrik, frekuensi, faktor daya dan daya aktif menggunakan modul PZEM-004T yang memiliki persentase penyimpangan pengukuran sebesar $1,07 \%$. Kinerja dari perangkat LoRa Ra-02 SX1278 yang digunakan menunjukan bahwa pada kondisi LOS diperoleh jarak maksimal jangkauan LoRa yaitu 195 meter dan pada kondisi NLOS diperoleh 90 meter. Pengujian keberhasilan transmisi data LoRa menggunakan satu buah node transmitter memperoleh persentase keberhasilan sebesar 100\%, sedangkan untuk transmisi data menggunakan dua buah node transmitter diperoleh persentase keberhasilan sebesar 96\%.

Penyimpanan data pada alat monitoring listrik tiga fasa ini dibagi menjadi penyimpanan pada database melalui server menggunakan jariangan internet dan data ditampilkan pada web monitoring dalam bentuk bentuk tabel dan grafik. Penyimpanan cadangan ke dalam mikro SD card dilakukan saat ESP32 pada node receiver tidak terhubung dengan jaringan internet.

\section{REFERENSI}

[1] S. Mustafa dan M. Umar. Rancang Bangun Sistem Monitoring Penggunaan Daya Listrik Berbasis Smartphone. Jurnal Media Elektrik, v. 17, n. 03 , p. 55-62, Agustus 2020.

[2] B. Prayitno, P. Palupiningsih, H.B. Agtiadi. Prototipe Sistem Monitoring Penggunaan Daya Listrik Peralatan Elektronik Rumah Tangga Berbasis Internet of Things. Jurnal Petir, v. 12, n. 1, p. 72-80, Maret 2019.

[3] S. Wasoontarajaroen, K. Pawasan, V. Chamnanphrai. "Development of an IoT Device for Monitoring Electrical Energy Consumption", in Proc. ICITEE, 2017.

[4] A.R. Susanto, A. Bhawiyuga, K. Amron. Implementasi Sistem Gateway Discovery pada Wireless Sensor Network (WSN) Berbasis Modul
Komunikasi LoRa. Jurnal Pengembangan Teknologi Informasi dan Ilmu Komputer, v. 3, n. 2, p. 2138-2145, Februari 2019.

[5] M.I. Suga dan H. Nurwarsito. Sistem Monitoring KWH Meter Berbasis Modul Komunikasi LoRa. Jurnal Pengembangan Teknologi Informasi dan Ilmu Komputer, v. 5, n. 4, p. 1257-1266, April 2021.

[6] R. Darmawan dan R.A. Setyawan. Rancang Bangun Sistem Monitoring Arus dan Tegangan Solar Cell Berbasis Komunikasi LoRa SX1278. Jurnal Mahasiswa TEUB, v. 6, n. 5, 2018

[7] Alfan, P. Murdiyat, L.H. Gunanto. Rancang Bangun Sensor Node Untuk Sistem Monitoring Energi Listrik Nirkabel Pada Gedung Dalam Kampus Politeknik Negeri Samarinda. PoliGrid, v. 2, n. 1, p. 1-9, Juni 2021.

[8] W.H. Hayt, Jr, J.E. Kemmerly, S.M. Durbin. Engineering Circuit Analysis. New York, United States of America: McGraw Hill, 2012, Ed. $8^{\text {th }}$.

[9] P. Scherz dan S. Monk. Practical Electronics for Inventors. United States of America: McGraw Hill, 2016, Ed. $4^{\text {th }}$.

[10] I.P. Meyyasa, R.S. Hartati, I.B.G. Manuaba. Analisa Kualitas Daya Listrik Instalasi Wing Amerta RSUP Sanglah Denpasar. Majalah Ilmiah Teknologi Elektro, v. 18, n. 2, p. 249-257, Mei-Agustus 2019.

[11] P.A. Juliantara, I.W.A. Wijaya, C.G.I. Partha. Rancang Bangun Kapasitor Bank Otomatis Berbasis Mikrokontroler ATmega 328P Untuk Perbaikan Faktor Daya, Jurnal SPEKTRUM, v. 5, n. 1, p. 157-163, Juni 2018.

[12] M.Z. Elfirman dan M. Alkaff. Pemanfaatan Wireless Sensor Network Berbasis Internet of Things Untuk Monitoring Lahan Gambut Jarak Jauh Jurnal Ilmiah Ilmu Komputer, v. 13, n. 1, p. 56-59, Februari 2018.

[13] S. Anwar, T. Artono, Nasrul, Dasrul, A. Fadli. "Pengukuran Energi Listrik Berbasis PZEM-004T", in Proc. Seminar Nasional Politeknik Negeri Lhokseumawe, 2019, v. 3, n. 1, p. A272-A276,

[14] R. Hidayat, I.M.A. Nrartha, I.B.F. Citarsa. Rancang Bangun Smart kWh Meter 3 Fase Dengan Komunikasi SMS Gateway. Dielektrika, v. 7, n. 2, p. 140-148, Agustus 2020 .

[15] I.G.A.M.Y. Mahaputra, I.G.A.P.R. Agung, L. Jasa. Rancang Bangun Sistem Keamanan Sepeda Motor Dengan GPS Tracker Berbasis Mikrokontroler dan Aplikasi Android. Majalah Ilmiah Teknologi Elektro, v. 18, n. 3, p. 361-367, September - Desember 2019.

[16] Y. Hakiki dan Y. Rahayu. Analisa Performansi LoRa pada Sistem Absensi Mahasiswa. Jom FTEKNIK, v. 7, n. 2, p. 1-9, Juli - Desember 2020.

[17] D.M.B.P. Wija, I.G.A.P.R. Agung, P. Rahardjo. Rancang Bangun Sistem Konversi Uang Logam Menjadi E-Money Berbasis Mikrokontroler dan Aplikasi Android. Jurnal SPEKTRUM, v. 8, n.1, p. 206-215, Maret 2021.

[18] I.I.W.R.I. Parmana, C.G.I. Partha, N.P.S. Utama. Rancang Bangun Sistem Monitoring Arus Beban pada Gardu Distribusi Menggunakan Short Message Service. Majalah Ilmiah Teknologi Elektro, v. 17, n. 1, p. 17-24, Januari-April 2018.

[19] R.A.G. Ramadhianti, C.G.I. Partha, I.G.A.P.R. Agung. Rancang Bangun Monitoring Energi Listrik Menggunakan SMS Berbasis Mikrokontroler ATMEGA328. Jurnal SPEKTRUM, v. 5, n. 1, 130-138, Juni 2018.

[20] N. Nurmalasari, A. Anna, R. Arissusandi. Rancang Bangun Sistem Informasi Akuntansi Laporan Laba Rugi Berbasis Web pada PT. United Tractors Pontianak. Jurnal Sains dan Manajemen, v. 7, n. 2, p. 6-14, September 2019 